
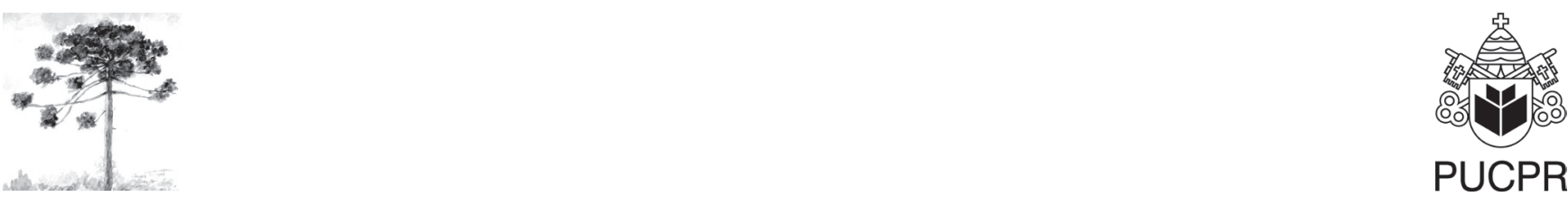

PUCPR

\title{
INTERFERENCE OF Bothrops jararacussu AND Bothrops cotiara VENOMS UPON BLOOD COAGULATION PATHWAYS
}

\author{
Interferência dos venenos de Bothrops jararacussu e Bothrops cotiara \\ sobre as vias da coagulação sanguinea
}

\author{
Fabiane Barchiki $^{[a]}$, Luiz Fernando Pereira ${ }^{[b]}$, Selene Lobo Elifio-Esposito ${ }^{[c]}$ \\ [a] Biólogo, Curso de Biologia da Pontifícia Universidade Católica do Paraná (PUCPR), Curitiba, PR - Brazil. \\ [b] Professor, phD, Curso de Biologia da Pontifícia Universidade Católica do Paraná (PUCPR), Curitiba, PR - Brazil, e-mail: \\ fernando.pereira@pucpr.br \\ ${ }^{[c]}$ Professor, phD, Curso de Biologia, Laboratório de Fisiologia Animal, Centro de Ciências Biológicas e da Saúde, Pontifícia \\ Universidade Católica do Paraná (PUCPR), Curitiba, PR - Brazil, e-mail: selene.e@pucpr.br
}

\begin{abstract}
Hemostasis includes mechanisms for the hemodynamic balance and integrity of the cardiovascular system. Overflow of blood provoke as an answer the activation of coagulation cascade which leads to a clot of fibrin. Snake venoms affect different interaction processes within the haemostatic system. Coagulation time (CT) were determined by the addition of venom samples to human plasma at 37OC. Minimum coagulant dose (MCD) was measured by the incubation of human plasma to venom sample in decreasing concentrations in two-fold serial dilutions (from $50 \mu \mathrm{g} / \mathrm{ml}$ ). For thrombin (TT) and prothrombin time (PT) $100 \mu \mathrm{l}$ of citrated plasma were incubated at $37^{\circ} \mathrm{C}$ for $60 \mathrm{sec}$ followed by the addition of $200 \mu \mathrm{l}$ specific reagent (bovine thrombin and thromboplastin, respectively). B. jararacussu venom presented TC of $29.4 \mathrm{sec}$ and DMC of $250 \mathrm{mg} / 1$. For B. cotiara venom TC was $30.2 \mathrm{sec}$ and DMC $125 \mathrm{mg} / \mathrm{l}$. Results suggested that both snakes venoms acted upon the common pathway.
\end{abstract}

Keywords: Blood coagulation. Bothropic venom. Thrombin. Prothrombin.

\section{Resumo}

Hemostasia inclui mecanismos de balanço hemodinâmico e integridade do sistema vascular. O vazamento de sangue provoca como resposta a ativação da cascata da coagulação que leva à formação de uma malha de fibrina. Os venenos de serpentes afetam diferentes processos de interação no sistema 
hemostático. O tempo de coagulação (CT) foi determinado pela adição de amostras do veneno ao plasma humano a $37^{\circ} \mathrm{C}$. A dose minima coagulante (MCD) foi medida pela incubação do plasma humano a amostras dos venenos em concentrações decrescentes em diluições seriadas (a partir de 50 $\mu \mathrm{g} / \mathrm{ml}$ ). Para o tempo de trombina (TT) e de protrombina (PT) $100 \mu \mathrm{l}$ de plasma citratado foi incubado a $37^{\circ} \mathrm{C}$ por $60 \mathrm{seg}$, seguida da adição de reagente específico (trombina bovina e tromboplastina, respectivamente). O veneno de $\mathrm{B}$. jararacussu apresentou CT de 29,4 s e MCD de $250 \mathrm{mg} / \mathrm{l}$. Para o veneno de B. cotiara, TC foi de 30,2 s e DMC de $125 \mathrm{mg} / \mathrm{l}$. Ambos venenos agiram sobre a via comum da cascata da coagulação.

Palavras-chave: Coagulação sanguínea. Veneno botrópico. Trombina. Protrombina.

\section{INTRODUCTION}

Hemostasis includes mechanisms for the hemodynamic balance and integrity of the cardiovascular system. Overflow of blood provoke as a final answer platelet aggregation and simultaneously the activation of coagulation pathways. The classic coagulation cascade can proceed through the intrinsic pathway, initiated by surface activation due to exposure to subendothelial components of the vessel walls. Another more critical route of initiation is through the extrinsic pathway, triggered by a lipoprotein exposed from damaged tissue, called tissue factor. Both of these pathways result in the activation of factor $\mathrm{X}$ to $\mathrm{Xa}$, and the subsequent steps whichleads to the formation of the fibrin clot from the activation of fibrinogen by thrombin (1). The main action of thrombin is to catalyse the proteolysis of fibrinogen, a soluble plasma protein, to form fibrin monomers that are still soluble. Fibrin monomers then polymerise to form a gel of fibrin polymers that traps blood cells. Thrombin also activates coagulation factor V, factor VIII and factor XIII (2). After clot formation, once bleeding has been stopped, the continuity of the endothelium is restored and the fibrinolytic system is then activated and gradually dissolves the clot.

Snake venoms are complex mixtures of a large variety of proteins and peptides affecting the hemostatic system. Those components can present different action and can be classified as procoagulant, anticoagulant, fibrinolytic, vessel wall interactive, platelet inducers or inhibitor, and plasma protein activators (3). Although many snake venoms contain a number of hemostatically active components, no single venom contain all categories. Bothrops species are outstanding for the high clotting activity of their venoms, due to the presence of thrombin-like enzymes which transform fibrinogen into fibrin. Most of these enzymes differ from thrombin itself, because they can liberate only fibrinopeptide A from the fibrinogen molecule and do not activate coagulation factor XIII, resulting in the formation of a type of fibrin which is instable and can be easily destroyed by fibrinolytic system $(4,5)$. The investigation of the effects of different snake venoms on blood clotting is important in order to understand the mechanism of action of venom components aiming their use in therapeutics or laboratory assays of blood clotting.

The objective of the present investigation was to identify the in vitrointerference of B. cotiara and B. jararacussuvenom on plasma coagulation pathways. Eventually, the isolation of active compounds from these venoms will permit the study of their mechanism of action on blood coagulation itself and therapeutic applications.

\section{MATERIAL AND METHODS}

\section{Material}

Bothropsjararacussu and B. cotiara dried venom were kindly provided by Instituto Butantan (São Paulo, Brazil) and stored at $-20{ }^{\circ} \mathrm{C}$ until use. Briefly before coagulation assays venoms were reconstituted in saline solution $(\mathrm{NaCl}$ 0,9\%). TT, PT and APT'T reagents kits were from Dade Behring Inc. (Newark, USA). The coagulant tests were carried out at $37^{\circ} \mathrm{C}$ using human citrated plasma ( $0,38 \%$ sodium citrate solution) obtained from periferic blood from 20 volunteers.

\section{Experimental procedures}

Coagulation time (CT) were determined by the addition of $50 \mathrm{ml}$ of venom sample $(50 \mathrm{mg} /$ 
$\mathrm{ml}$ ) or PBS to $100 \mathrm{ml}$ of human plasma at $37^{\circ} \mathrm{C}$. Minimum coagulant dose (MCD) was measured by the incubation of $100 \mu$ l of human plasma to $50 \mu$ l of venom sample in decreasing concentrations in twofold serial dilutions (from $50 \mathrm{mg} / \mathrm{ml}$ ), as described by EVANS e KINI (1997). For thrombin (TT) and prothrombin time (PT) $100 \mathrm{ml}$ of citrated plasma were incubated at $37^{\circ} \mathrm{C}$ for $60 \mathrm{sec}$ followed by the addition of $200 \mathrm{ml}$ specific reagent (bovine thrombin and thromboplastin, respectively). On adding the reagent timer coagulometer was started to determine the coagulation time. In order to investigate venoms interference on coagulation tests, venom solution $(50 \mathrm{mg} / \mathrm{ml})$ was previously incubated with reagents before addition to test tubes.

\section{Statistical analysis}

Means and standard deviation of all data were obtained and compared by ANOVA followed by Tukey test, with significance probability levels of $\mathrm{p}<0.05$, using Statistica 5.1.1 program.

\section{RESULTS AND DISCUSSION}

Many snakes venom have long been known to affect blood coagulation. In the last few decades, a considerable amount of work on the mechanism of action of snake venoms in promoting or inhibiting blood coagulation process has been carried out (5, 6). In South America, venomous snakes comprise four distinct genera: Bothrops, Crotalus, Lachesis and Micrurus; among those only Micrurus produce venom which does not affect blood coagulation.

The effect of venom samples on coagulation of human plasma was analysed and our results confirm the procoagulation action of Bothrops venoms. Table 1 shows that at the concentration of $50 \mathrm{mg} / \mathrm{ml}$ both venoms induced coagulation in aprox. $30 \mathrm{sec}$. On the other hand serial dilution of venom samples in saline resulted in $125 \mathrm{mg} / \mathrm{L}$ for B.cotiara venom as the minimum coagulant dose (MCD) what points out B. cotiara venom twice more active than B. jararacussu venom. These results contrast from what has already been published in previous papers. Species from Costa Rica, Bothrops atrox, and B.schlegellii, exhibited MCD-P (minimum coagulant dose on plasma) of 1.4 and $13.2, \mathrm{mg} / \mathrm{L}$, respectively, whereas $B$. nasutus showed no more than trace activity on plasma (7). Analysis of Brazilian species revealed MCD-P from 19.3 to $90.6 \mathrm{mg} / \mathrm{L}$, specifically of 84.5 for B. cotiara and $42.8 \mathrm{mg} / \mathrm{L}$ for B. jararacussu (8). Such divergence may be explained by the the fact that the composition and the mechanism of blood coagulation activation by venoms varies among species. Theakston and Reid (1983) tested the activity of 45 Viperine venoms from diferent genera and showed that only 19 of them showed, at least, trace coagulant action on plasma. Even within the same species, variation can accur depending on the age of the snake (5, 9), season (10) and geographic distribution (11).

The last stage of the cascade is measured by thrombin time assay which consists in the conversion of fibrinogen to fibrin by the action of thrombin and the spontaneous polymerisation of the fibrin to form a soft clot. In the present work, thrombin time was significantly reduced by $B$. cotiara venom $(12.47 \mathrm{sec})$ when compared to control $(20.66 \mathrm{sec})$, whereas the venom of $B$. jararacussu promoted a minor decrease $(18.16 \mathrm{sec})$, statistically similar to control. On the other hand, on prothrombin time investigation (PT) showed an slight but significant reduction on coagulation time promoved by $B$. jararacussu venom, whereas B. cotiara venom increased time of clot formation in aprox. 20\%, compared to control $(18.12 \mathrm{sec})$. This method indicates the integrity of the extrinsic pathway of the coagulation cascade, in which both thromboplastin (factor III) and calcium are added to plasma independently activating prothrombin into thrombin.

At the present time more than 100 different snake venoms are known to affect the hemostatic system by a variety of mechanisms (12). Venoms that promote clotting can act by activating fibrinogen (Factor I), prothrombin (Factor II) (13), Factors X, V, IX and factor VIII $(12,14)$. Our results imply that the venoms of $B$. cotiara and $B$. jararacussu promote coagulation by thrombin-like enzymes and prothrombin activators, respectively, but further investigation is required to a complete understanding of their action.

\section{ACKNOWLEGEMENTS}

We thank the Instituto Butantan for providing B. jararacussu and B. cotiara venom. This research was supported by grants from PUCPR and PIBIC/CNPq, Brasil. 


\section{REFERENCES}

1. Evans HM, Kini RM. The anticoagulant effects of snake venom phospholipases A2. In: Kini RM. Venom phospholipase A2 enzymes: structure, function and mechanism. England: Wiley; 1997. p. 511.

2. Braud S, Bon C, Wisner A. Snake venom proteins acting on hemostasis. Biochimie. 2000;82(9):851-9.

3. White J. Snake venoms and coagulopathy. Toxicon. 2005;45(8):951-67.

4. Selistre HS, Giglio Jr. Isolation and characterization of a thrombin-like enzyme from the venom of the snake Bothrops insularis (Jararaca Ilhoa). Toxicon. 1987;25(11):1135-44.

5. Kamiguti AS, Sano-Martins IS. South american snake venoms affectin haemostasis. J. Toxicol - Toxin Reviews. 1995;14(3):359-74.

6. Ouyang C, Teng CM, Huang TF. Characterization of snake venom components acting on blood coagulation and platelet function. Toxicon. 1992;30(9):94566.

7. Theakston RDG, Reid HA. Development of simple standard assay procedures for the charactrization of snake venoms. Bull World Health Organ. 1983;61(6):949-56.

8. Furtado MFD, Colletto GMDD, Dias SW. Controle de qualidade dos venenos animais e dos correspondentes antivenenos. Mem Inst Butantan. 1991;53:149-59.

9. Gutierrez JM, Avila C, Camacho Z, Lomonte B. Ontogenetic chances in the venom of the snake Lachesis muta stenophrys (Bushmaster) from Costa Rica. Toxicon. 1990;28(4):419-26.

10. Gubensek F, Sket D, Turk V, Lebez D. Fractional of Vipera ammodytes venom and seasonal variatio of its composition. Toxicon. 1974;12:167-71.

11. Rocha MMT, Furtado MFD. Caracterização individual do veneno de Bothrops alternatus Duméril, Bibron \& Buméril em função da distribuição geográfica no Brasil (Serpentes, Viperidae). Revista Brasileira de Zoologia. 2005;22(2):383-93.

12. Markland FS. Snake venoms and the hemostatic system. Toxicon. 1998;36(12):1749-800.
13. Nahas L, Kamiguti AS, Barros M. Thrombin-like and factor X-activator components of Bothrops snake venoms. Thromb Haemost. 1979;41(2):314-28.

14. Kirby EP, Niewiarowski S, Stocker K, Kettner C, Shaw E, Budzynski TM. Thrombocytin, a serine protease from Bothrops atrox venom. 1. Purification and characterization of the enzyme. Biochemistry. 1979;18(16):3564-70.
Received: 06/24/2007

Recebido: 24/06/2007

Approved: $12 / 09 / 2007$

Aprovado: 09/12/2007 